Article

\title{
BIM Management Measure for an Effective Green Building Project
}

\author{
Reuven Maskil-Leitan ${ }^{1, *}$, Ury Gurevich ${ }^{2}$ (I) and Iris Reychav ${ }^{1(1)}$ \\ 1 Industrial Engineering \& Management Department, Ariel University, Ariel 40700, Israel; irisre@ariel.ac.il \\ 2 Government Office, Petach Tikva 4959253, Israel; ury.gurevich@gmail.com \\ * Correspondence: ruven.maskille@msmail.ariel.ac.il
}

Received: 29 June 2020; Accepted: 25 August 2020; Published: 27 August 2020

\begin{abstract}
In light of the gap in research and practice, with regard to achieving the sustainability goals of green building, while maximizing combination with building-information-modeling (BIM) as a social system - a gap that is expressed in the absence of integration of all stakeholders-a managerial measure is proposed to integrate them and promote sustainable green building. By using a framework for implementing BIM as a social system, and through network analysis, an index is developed to assess its integration into the green building-the Green BIM Index. This measure consists of comparing a social benchmark for optimal implementation with the actual implementation, in a given project. The index is intended to help score the BIM integration level in a green building. Comparing the BIM management measure results with social benefit assessments, and the effectiveness of BIM in nine case-studies enables to understand project outcomes in terms of schedules, budgets, and quality. The paper demonstrates the index applicability, pointing to possible significant economic improvements through the implementation of BIM social capabilities. BIM management benchmarking is helpful for the comparative evaluation of similar projects incorporating green building with BIM, indicating the level of integration to improve benefits.
\end{abstract}

Keywords: BIM; green building; benefits of BIM; public construction clients; project outcomes

\section{Introduction}

The use of building-information-modeling (BIM) as a promoter of green processes has received considerable attention among practitioners of the construction industry [1]. Given the momentum of BIM and green building applications, many construction companies have sought to leverage green building projects through BIM, in order to realize the synergies between them while achieving sustainability through them [2]. Green building is 'a holistic concept that starts with the understanding that the built environment can have profound effects, both positive and negative, on the natural environment, as well as the people who inhabit buildings' [3] (p. 1). It is 'an effort to amplify the positive and mitigate the negative of these effects' [3] (p. 1). BIM is a 'digital representation of physical and functional characteristics of a facility. A BIM is a shared knowledge resource for information about a facility forming a reliable basis for decisions' [4] (p. 1). The construction industry has been driven to adopt green building strategies from sustainability considerations, such as reducing $\mathrm{CO}_{2}$ emissions and energy dependency on fossil fuels. BIM has been regarded by many to be an opportunity for making the best use of the available design data for sustainable design and performance analysis [5]. The convergence of these separate trends into emerging practice has been referred to as green BIM [1].

BIM's technical advantages were soon joined to help facilitate more effective processes related to budget control, schedules, and environmental data, in an effort to increase green building effectiveness [6]. Green BIM has been perceived as a combination of green building, required to address environmental issues [7], with BIM as a technical tool [8], which serves it. However, 
incorporating BIM, as a socio-technical system, into green building, as sustainable construction, also requires consideration of the social component involved in achieving effectiveness.

Green building integration with BIM can be presented as one that necessitates coordination among many involved, using sophisticated modeling and system analysis to bring about a sustainable project. This combination requires managerial capabilities to improve efficiency [9]. However, alongside measurement systems-mostly environmental—for green building, and alongside mostly technical indicators-for BIM, there is no benchmarking system for examining these capabilities in green BIM.

In light of the gap in research and practice, with regard to achieving the sustainability goals of green building, while maximizing combination with BIM as a social system-a gap that is expressed in the absence of integration of all stakeholders-a managerial measure is proposed to integrate them and promote sustainable green building. The measure for this implementation of the social system - the integration of BIM in the interactions between all those involved in the project-emphasizes the reliance on an intra-firm organizational structure for the realization of a sustainable purpose. Presenting green BIM as a combination that requires high levels of interaction between participants and complex technology systems, the paper highlights the need for social integration through stakeholder management. The purpose of the research is to explain the importance of addressing this need to achieve effectiveness and to offer it an appropriate response.

In order to refer to the green BIM in this social context, this study uses a corporate-socialresponsibility (CSR) model for BIM application as a benchmark for evaluating this integration and promoting its benefits. From this social point of reference to the agreements and working relationships between parties to a given project, the participation of stakeholders in the organization is examined, and their connection to the construction process is assessed. Considering that industrial practice scarcely includes reference to social components of sustainability, this study suggests bridging the gap using a CSR-based BIM index: the Green BIM Index. This metric refers to the basic question of whether and how social sustainability can be measured [10], by considering a green building project as a means of achieving sustainable benefits, and by presenting practical BIM-based indicators for assessing social sustainability in green building projects. According to the proposed measure, the BIM implementation is calculated by the CSR benchmark for a given project as a standard, and a match is made between its results and the actual BIM implementation results, using social-network-analysis (SNA). The need for collaboration is evident in times of crisis, such as the COVID-19 pandemic, when work is done remotely. A socially-based BIM may help achieve quality as a result of conducting a proper collaborative process.

The index is examined and applied in nine case-studies to confirm its validity and to examine its effectiveness by comparing the actual use of BIM methodology, the social benefits, and the objective effectiveness of the project. In this study, a special emphasis is placed on data quality in order to establish the index. Accordingly, green public projects of the owner-occupier type are carefully chosen and assessed at various project stages, to allow for an appropriate comparison of all model criteria and evaluation. The attempt is to raise awareness of the planning method and the concept of sustainability to achieve success [11]. This demonstration of social integration expands the understanding of CSR as required to implement BIM's social role in the industry while presenting practical means to promote a sustainable green building project.

\section{Background}

\subsection{Effective Green BIM-Social Characteristics and Requirements for Sustainable Benefits}

The integration of the green building with BIM is a combination of a highly complex project-based organization and sophisticated environmental modeling and analysis systems, which require managerial responsibility for achieving broad sustainable benefits. Its characteristics and requirements, as indicated by the literature, are presented below.

In contrast to the traditional work methods, the management of design information and processes integration in green building planning involves a wider range and a larger number of consultants, 
using sophisticated environmental modeling and analysis systems. A comprehensive understanding of the multi-level interconnections between technologies, people, project phases, processes, and systems is needed to address the green BIM requirements [12]. Green BIM requires consideration of processes and technologies, as well as an information management strategy that supports inter-organizational collaboration for a sustainable project. Hence, the effective management of information is likely to require an extensive dialogue with stakeholders to meet these green BIM requirements. Moreover, in a detailed examination of the integration of BIM technology with green practices, in order to achieve the sustainable environmental benefit, the need to achieve social benefit is revealed. It turns out that alongside the technical issues-which include references to software [13], technical skills [14], and the technological process [15] - there is a need for access [16] and awareness of all the parties involved in the project [17]. Moreover, in evaluating the success factors that can increase the connection between BIM and green building, it has been found that stakeholders have an important part in this, in light of the fact that among the first factors is their level of awareness and involvement [18]. The full application of green BIM thus requires reference to social integration alongside technical integration.

The literature review provides some important insights on optimizing the effective adoption of BIM for sustainability, which involves the need for an appropriate collaborative practice [19]. It turns out that the overall level of collaboration in the common data environment is not at a threshold level enough to realize BIM's full potential [20]. Moreover, conventional contractual measures do not appear to be compatible with the characteristics of BIM. Thus, some studies have begun to examine an integrative approach for addressing social issues. Integrated-project-delivery (IPD) has been proposed to improve communication and collaboration, enabling sustainable achievement [14]. Against this backdrop, the need for empirical research has been raised to learn the best practice of providing BIM for better social sustainability [21].

It is, therefore, possible that the prevailing combination of green buildings and BIM, a combination that has received considerable coverage in the literature [22], does not fully fulfill its purpose. Although BIM has been proposed as a solution to common obstacles in green construction, which include cost overruns and delays related to increasing design and construction complexity, the proposals are required to address the fact that this solution is a function of the full realization of its social dimension. In view of this, a means is needed to examine the realization of BIM's social capacity in this combination.

\subsection{Means of Implementing Social Integration through BIM for Sustainable Green Building}

In order to address the need to integrate stakeholders in green BIM and to make full use of the socio-technical integration, appropriate guidance and evaluation measures are required. The following lines have reviewed various possible measures to promote social sustainability in the construction industry, as part of an attempt to achieve, through BIM, a sustainable green building project.

The green building assessment tools have been developed with the aim of assisting in the implementation of sustainable development in the construction industry. However, they lack a detailed analysis of the social aspect of sustainable development [23]. Furthermore, BIM integration can provide information to support the calculation of a number of credit points to define goal levels of sustainability associated with green building rating systems [24]. It allows the evaluation of multiple design scenarios simultaneously, environmentally, and financially [25]. However, there is no comprehensive assessment and measurement tool to promote social sustainability through BIM in green building.

In an attempt to promote social sustainability in the construction industry, it has been suggested to use social-network-analysis [26] and apply it to construction-where a project-based organization is prevalent [27]. While identifying the status of the stakeholders within the social network of a project indeed allows an assessment of the social value obtained from it, there is no standard for achieving this value in a green building project. Therefore, the study has used this view to present a normative approach for the application of BIM in green building by SNA. Based on a socio-technical perspective that presents the implementation of BIM as an influencing factor for the project-based organization, 
and considering the importance of BIM's social application for achieving sustainable green building, this study presents a standard for its application, as well as an SNA measure for its assessment.

In addition, the need to promote sustainable development in the construction industry has led to the development of a framework to assess the performance of the corporate-social-responsibility of the construction corporation [28]. Different indicators should provide guidance for the implementation of social responsibility in the construction industry and allow organizations to build and assess the performance of social responsibility, which, in turn, could assist in achieving sustainable business development. However, it seems that for purposes of presenting CSR indicators, a transparent weight system is required, as well as an examination of stakeholders' interactions [28].

CSR is based on the premise that organizations need to behave in a socially responsible manner [29]. It is also possible to point out the complementarity of CSR and stakeholder theory [30]. This theory recognizes that organizations have commitments not only to shareholders but also to other interest groups, such as customers, employees, suppliers, and the wider community [31,32]. Sustainable development, corporate sustainability, and CSR are closely related to stakeholder relationship management, but at different levels of performance. While sustainable development is a guiding model at the society level, and corporate sustainability is a sustainable development model at the corporate level, CSR is a management approach to business contribution for sustainable development [29]. On this basis and for the purpose of this paper, CSR is defined as a corporate management approach that addresses all stakeholders involved in a construction project in an attempt to realize their sustainable benefits within business processes that include the use of BIM. Mapping of information transfer through BIM may facilitate the examination and evaluation of interactions between the corporate stakeholders. Therefore, this study uses the BIM application to promote sustainable green building while presenting a standard and CSR-based SNA index for its evaluation.

\section{Formulation and Application of Standard and Index for Social Integration in Green BIM}

\subsection{Proposed Standard for Social Integration in Green BIM}

In response to the need for social integration to achieve sustainable goals of green BIM, a CSR-based BIM application model is presented. In terms of relevant guidelines for the application of BIM as a social system - the CSR-based model includes elements for achieving social sustainability, which, according to this paper hypothesis, enable effective green building. Social sustainability components include; fairness, which provides equal opportunities for all; awareness, which fosters alternative consumption habits; participation, which relates to the inclusion of as many groups as possible in decision-making; cohesion, which strengthens community integration [33]. In addition, in terms of suitable project delivery conditions, the integrated-project-delivery (IPD) method includes contractual components that reinforce the BIM application model for achieving sustainable green building. IPD is a method that attempts to align interests by a group-based attitude. The main group participants consist of the owner, architect, general contractor, and major consultants. Beyond IPD principles according to industry definitions-including multi-party agreement, early involvement of all parties, and shared risk and reward-a survey has found that 'good leadership is required to encourage a collaborative team environment' [34]. Moreover, the IPD vision includes the involvement of end-users at the beginning of the planning process [35]. This method gains different levels of detail and application [36]. The broad definition refers to many owners, mainly public owners, who are not authorized to enter multi-party agreements and to bring subcontractors into the planning process. However, to take advantage of some of the key benefits of IPD-type delivery, many contractual provisions and project procedures can be modified. These include bringing the construction manager $(\mathrm{CM})$ to the project at the beginning of the process, co-location of the team, and establishing a team decision-making process and structure [37]. The classification of social sustainability components-in the combination of BIM and the interrelations between those involved in a project-mirrors relationships with stakeholders of a responsible construction corporation in terms of CSR interpretation. This enables improved 
management of all involved, professionals and non-professionals alike, throughout all phases of the building. The carefully shaped project-based organization can be quantified and evaluated as a basis for comparison in terms of social networks. A social network is based on a set of actors and the relationships between them [38]. With the use of social network theory and social-network-analysis, it is possible to describe and analyze interactions between participants in construction projects [39-43]. Five levels of social sustainability are identified and classified according to CSR for a green building project [44]. These levels are adapted to IPD and are translated into SNA indices [45]. The criteria for this model, with their indices, are becoming a benchmark-The BIM Integrated Application Standard-for evaluating the socio-technical integration and promoting its benefits. Given that standardization is a key enabler for advancing BIM implementation [46], this specific standard is proposed to promote the implementation of BIM's social potential in green building. Standard components, which include (1) stakeholder management-through BIM manager centrality, (2) use of a BIM-based social network, (3) benefits through connecting all stakeholders, (4) and tenants, to the BIM manager, are presented below in describing the benchmark index (A detailed conceptual description is given in Appendix A).

\subsection{Green BIM Index}

The proposed examination is consistent with the trend in literature to introduce formal and informal institutions that influence a project-based organization [47]. As a result, the use of BIM is presented as another factor shaping this organization. However, unlike the tendency in studies to examine formal institutions, such as project delivery contracts, alongside informal institutions, such as work practices, the proposed examination is in relation to an external reference point. In view of the gap reflected in the BIM guidelines and the various valuation methods, in terms of achieving the sustainable goals of green building, and given the importance of BIM's social integration to achieve them, it is proposed to compare its actual combination with its optimal one; i.e., a standard combination in a given project. This comparison by standard criteria is conducted using the components of the Green BIM Index.

\subsubsection{Index Components}

1. Stakeholder management ratio—-weighted degree centrality index (X1). This measure constitutes a means for assessing the implementation of the stakeholder management criterion, by presenting the ratio between the actual weighted degree and a standard weighted degree, in relation to the BIM manager in each project. In this way, the degree of centrality of the BIM manager, as a management implementer for stakeholders, relative to the required level, is reflected. The use of this index component enables the realization of the full potential of BIM leadership in a given project (Equation (A2) in Appendix B).

2. Stakeholder participation ratio-BIM-based social networking cluster index (X2). This measure constitutes a means for assessing the implementation of the stakeholder participation criterion by presenting a ratio between the number of project participants connected to a BIM-based social network and the optimal number of connections. In this way, the participation of stakeholders, relative to nodes identified, as required in a BIM-based network, is reflected. This index component enables the examination of the promotion of collaboration in a given project (Equation (A3) in Appendix B).

3. The ratio of professional involvement-ego network cluster index of BIM manager (X3). This measure serves as a means to assess the implementation of the engagement criteria of all professionals by presenting a ratio between the number of direct links to the BIM manager and the optimal number of links. The index component enables examination of the connectivity of the professional team, including the contractor or the construction manager, already at the design phase of the building (Equation (A4) in Appendix B).

4. The ratio of tenant involvement-ego network cluster index of tenant representative (X4). This measure serves as a means to examine the implementation of the engagement criterion of all 
non-professionals by presenting a ratio between the number of their direct connections to their representative and the optimal number of connections. The ego network cluster index enables the examination of connectivity, in terms of tenants and end-users, through their representatives, from the design phase of the building (Equation (A5) in Appendix B).

5. The ratio by stage (X5). As part of comparing the actual use to the standard, which reflects a project reference, the index enables the application of the criteria to be considered throughout the phases of the building. This examination is based on the calculations of the indices at each phase within a project (Equation (A6) in Appendix B).

\subsubsection{Demonstrating the Way to Use Index Components}

The way to use the components of the index is illustrated below, in a specific example of a project that combines BIM in green building. The examination of the integration between the two is performed using three tables: SNA results table for the actual implementation of BIM in green building (Table 1), SNA results table for optimal implementation of BIM in green building, according to standard assumptions (Table 2), and table of findings of the Green BIM Index (Table 3). This project relates to a detailed design stage of a cafeteria. Although the standard assumption in the given project refers to 12 required stakeholders, in practice, two of them did not participate in the sample (the tenant and the landscape architect).

Table 1. SNA results for the actual implementation of BIM in green building.

\begin{tabular}{clccc}
\hline \multicolumn{5}{c}{ Actual Implementation Results } \\
\hline ID & \multicolumn{1}{c}{ Label } & $\begin{array}{c}\text { Weighted } \\
\text { Degree }\end{array}$ & $\begin{array}{c}\text { Weighted } \\
\text { Out-Degree }\end{array}$ & $\begin{array}{c}\text { Weighted } \\
\text { In-Degree }\end{array}$ \\
\hline 1 & AC engineer & 43 & 13 & 30 \\
2 & Architect & 55 & 20 & 35 \\
3 & BEM Specialist & 28 & 3 & 25 \\
4 & Tenant & 0 & 0 & 0 \\
5 & Constructor & 37 & 10 & 27 \\
6 & Electrical engineer & 38 & 10 & 28 \\
7 & Cafeteria consultant & 67 & 25 & 42 \\
8 & Landscape architect & 0 & 0 & 0 \\
9 & Plumbing Consultant & 42 & 12 & 30 \\
10 & Project Manager & 22 & 0 & 22 \\
11 & Regulatory advisor & 28 & 3 & 25 \\
12 & BIM manager & 228 & 198 & 30 \\
\hline
\end{tabular}

Table 2. SNA results for optimal implementation of BIM in green building.

\begin{tabular}{clccc}
\hline \multicolumn{5}{c}{ Optimal Application Results } \\
\hline ID & \multicolumn{1}{c}{ Label } & $\begin{array}{c}\text { Weighted } \\
\text { Degree }\end{array}$ & $\begin{array}{c}\text { Weighted } \\
\text { Out-Degree }\end{array}$ & $\begin{array}{c}\text { Weighted } \\
\text { In-Degree }\end{array}$ \\
\hline 1 & AC engineer & 27 & 5 & 22 \\
2 & Architect & 27 & 5 & 22 \\
3 & BEM Specialist & 23 & 1 & 22 \\
4 & Tenant & 23 & 1 & 22 \\
5 & Constructor & 27 & 5 & 22 \\
6 & Electrical engineer & 27 & 5 & 22 \\
7 & Cafeteria consultant & 23 & 1 & 22 \\
8 & Landscape architect & 23 & 1 & 22 \\
9 & Plumbing Consultant & 27 & 5 & 22 \\
10 & Project Manager & 23 & 1 & 22 \\
11 & Regulatory advisor & 23 & 1 & 22 \\
12 & BIM manager & 273 & 242 & 31 \\
\hline
\end{tabular}


Table 3. Green BIM Index findings.

\begin{tabular}{lccc}
\hline BIM Integrated Application Standard & \multicolumn{2}{c}{ Project Results } & Green BIM Index \\
\hline Components & Actual & Optimal & Components \\
\hline $\begin{array}{l}\text { Participants connected to a BIM-based } \\
\text { social net }\end{array}$ & 9 & 11 & 0.8 \\
\hline Connections with professionals & 9 & 10 & 0.9 \\
\hline Connection with a tenant representative & 0 & 1 & 0 \\
\hline $\begin{array}{l}\text { BIM for stakeholder } \\
\text { management-weighted degree }\end{array}$ & 228 & 273 & 0.84 \\
\hline Score & & & 0.64 \\
\hline
\end{tabular}

The assumption for a BIM manager is that he/she sends information to everyone daily, receives information from key participants on a daily basis, receives information from the secondary to them on a weekly basis while receiving from other participants on a monthly basis. In the example, the BIM manager did send information as required but did not receive a standard response (some sent on a weekly basis, and some did not send at all). The assumption results in a weighted degree of 273 compared to 228 in practice, resulting in an index finding of 0.84 (X1).

In addition, according to the standard, all involved, professionals and tenants alike, should be connected, directly or indirectly, to a BIM-based social network. This is reflected in 11 optimal connections versus nine actual connections, resulting in an index finding of 0.8 (X2).

Besides, the standard assumption is that there is no interaction but through a BIM-based network and with a BIM manager or agents. This is shown in the result of 10 optimal connections of professionals compared to nine of their actual connections and in an index finding of 0.9 (X3). This is in addition to one optimal connection of a tenant representative compared to 0 connections of an actual tenant representative and to an index finding of 0 as a result (X4).

The Green BIM Index score in relation to the BIM application at the detailed design stage in the green building project is 0.64 (X5). This index can be used as a means of improving capabilities in additional stages. Figure 1 graphically shows the performance metrics at the given stage.

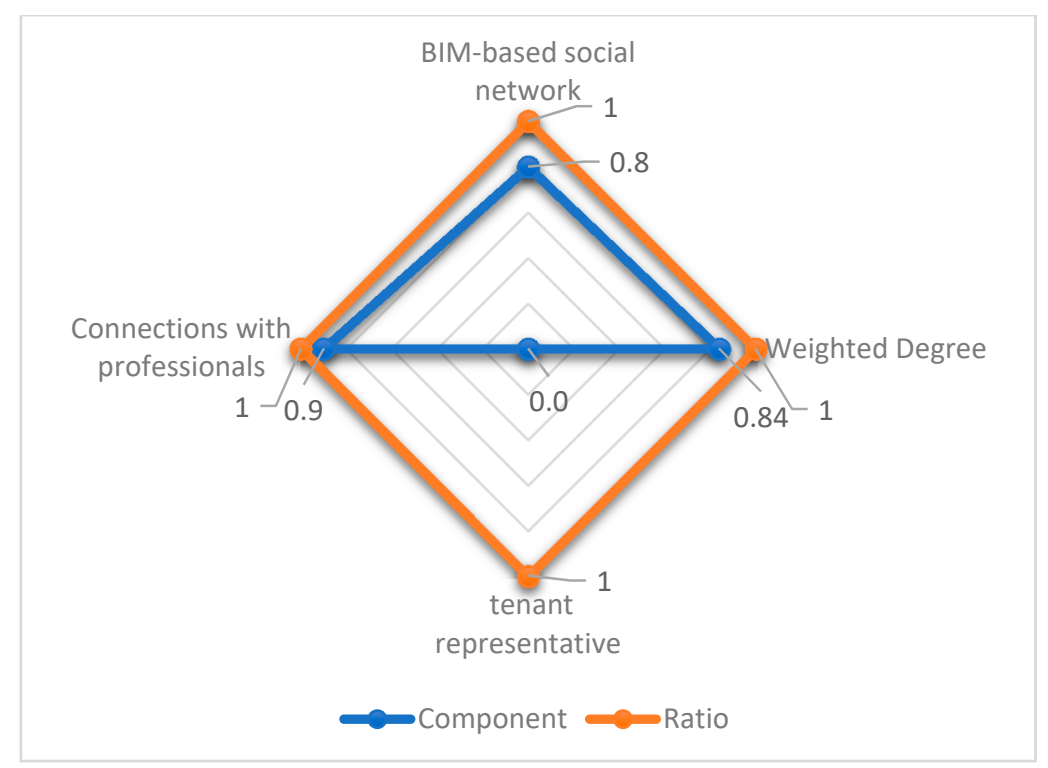

Figure 1. Graphical display of the Green BIM Index components. 


\section{Research Method}

\subsection{Applying CSR for Sustainable Benefits of Green BIM Using SNA}

It turns out, then, that the green BIM is not only a combination with a purely technical environmental dimension but also a combination with a complex human aspect, which requires an overall social reference. This includes managing a large number of participants, including end-users with real environmental interests, as well as other interests associated with their connection to the building. Implementing green BIM through CSR may facilitate the social paradigm shift in the construction industry to achieve effectiveness for all involved. Reflecting green BIM performance on quantitative measures to assess the various interactions of a BIM combination in a green building project may be a significant tool for evaluating this application.

The research workflow outlined in Figure 2 presents the measures taken across the various parts of the research to present an applicable benchmark for broad social integration of BIM with green building. The study begins with a comprehensive review of the literature on green BIM to identify social characteristics and requirements for sustainable benefits. Different tools are examined in terms of social integration in order to achieve sustainable green building. The results illustrate the absence of effective integration between BIM and green building and the lack of suitable means for its evaluation (top row in Figure 2). This serves as the basis for the implementation of a CSR-based model for the BIM application, adapted to the IPD method and quantified by SNA. Based on the SNA indices for comparing actual results and optimal results—according to the standard—of the BIM system, the possibility of maximal integration of BIM with the green building is proposed. In addition, this systemic perception is examined using a participant questionnaire to assess the social sustainability benefits alongside effectiveness in a given project (middle row in Figure 2). Comparison and validation of this measure are conducted in nine case-studies, reflecting deferent types and stages of a project (the bottom line in Figure 2).

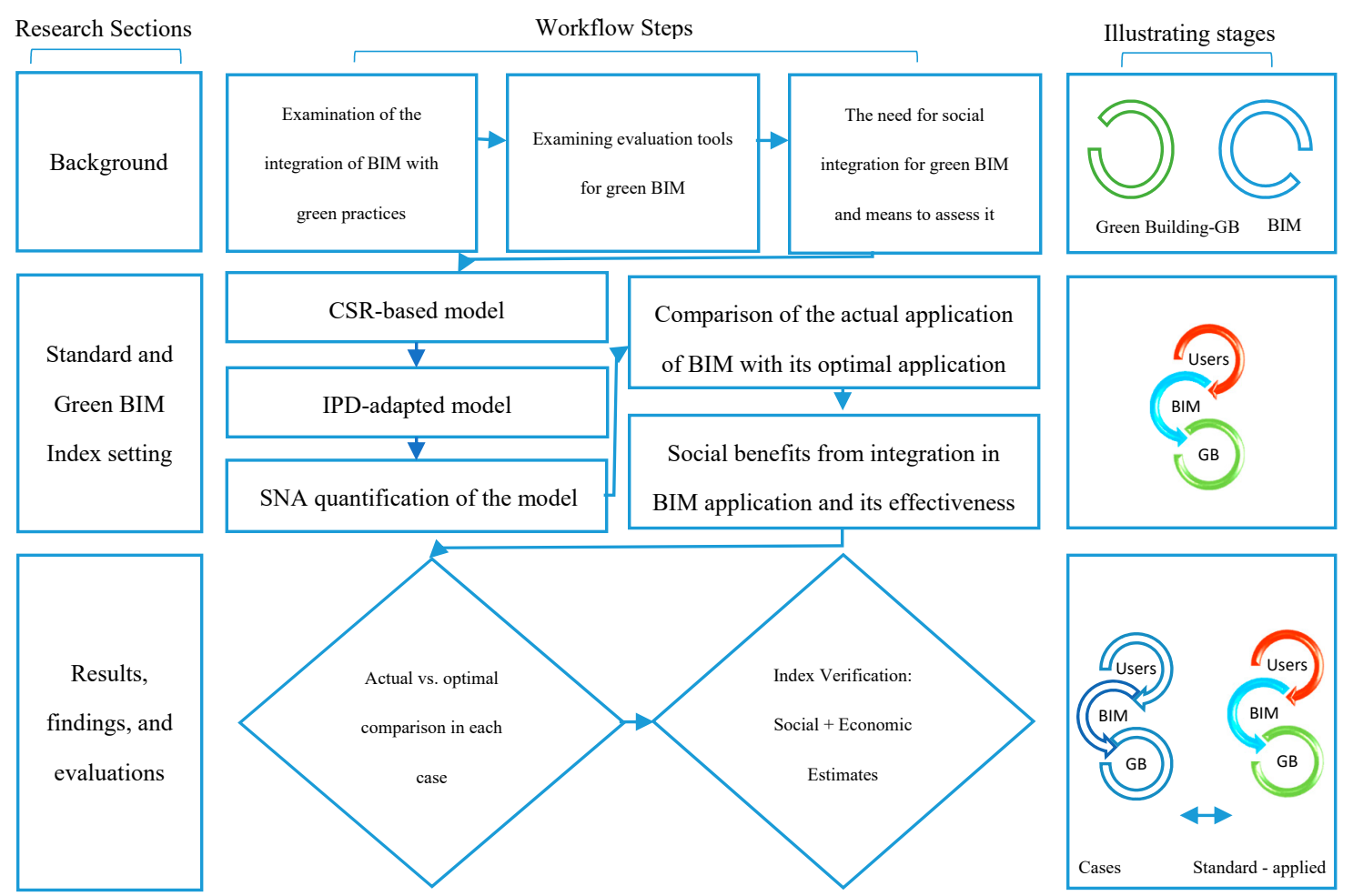

Figure 2. Outline of the research workflow. 


\subsection{The Case-Study Approach}

The index proposed in this paper is intended to serve as a means of measuring social integration in a green BIM in an attempt to realize its benefits. In order to demonstrate and evaluate the implementation of the Green BIM Index, the case-study approach is selected. This approach is considered most appropriate for this research inquiry, as it tries to construct realistic representations of project-related communications in uncontrolled surroundings [48]. In the absence of a comprehensive study on the social perception of BIM in green building projects, and in order to attain certainty [49], green building cases that incorporate BIM are selected to examine the possibility of achieving effectiveness in this building through this socio-technical system.

For a thorough examination of the model implementation, we have chosen to focus on public projects. In Israel, public projects are taking the main share of green BIM. The public sector is often characterized by the publication of project auctions in which it is owner-occupier-allowing accessibility to examine the implementation of all parts of the model, including involving end-users. The urban public sector usually allows the end-user community to be located, so we have chosen two municipal projects, which incorporate office dwellers or end-users at the planning stage. The two selected projects are located in cities that belong to the 15 cities forum that incorporates most of the largest cities in Israel, which has taken on the integration of green building. Both are designed by the same architect and by the same green building consultant, with the desire to integrate the constructor manager, so the selection has allowed a comparison on a similar basis. The government public sector is a major client in the construction industry that uses BIM and assimilates the green building principles through threshold requirements for tenders. This sector allows the examination of large-scale projects, so we have chosen to compare seven projects from it-two projects of each type/budget, stage, and even architectural teams at the same stage in a project. In this way, the selection allows for a broad comparison of BIM social implementation on an equal basis. The types of projects and the clear separation between the design phase and the execution phase in this sector have resulted in adapting the model to the different number of stakeholders in each. Table 4 shows the key characteristics of the carefully chosen projects. In the various cases selected, the attempt is to validate the findings of the proposed index with the results of the social benefit assessment and the effectiveness of incorporating BIM in green building. The following sections describe how data is collected and analyzed in an attempt to show how measurement is performed and confirmed.

Table 4. Characteristics of the projects.

\begin{tabular}{ccccccc}
\hline No. & Project & Stage & Purpose & Budget & Size & Features \\
\hline 1 & Municipality project & Conceptual design & City Hall & $\$ 24,548,913$ & $4151 \mathrm{~m}^{2}$ & Downtown area \\
2 & Municipality project & Conceptual design & Central station & $\$ 67,789,183$ & $27,620 \mathrm{~m}^{2}$ & Downtown area \\
3 & Government project & Conceptual design & Catering & $\$ 2,857,143$ & $530 \mathrm{~m}^{2}$ & Rural area \\
4 & Government project & Conceptual design & Campus & $\$ 42,857,143$ & $20,900 \mathrm{~m}^{2}$ & Suburban area \\
5 & Government project & Detailed design & Catering & $\$ 10,000,000$ & $3400 \mathrm{~m}^{2}$ & Rural area \\
6 & Government project & Detailed design & Campus & $\$ 10,000,000$ & $3000 \mathrm{~m}^{2}$ & Rural area \\
7 & Government project & Construction & Catering & $\$ 6,285,714$ & $1686 \mathrm{~m}^{2}$ & Rural area \\
8 & Government project & Construction & Campus-Part 1 & $\$ 52,571,429$ & $13,400 \mathrm{~m}^{2}$ & Rural area \\
9 & Government project & Construction & Campus-Part 2 & $\$ 58,000,000$ & $16,700 \mathrm{~m}^{2}$ & Rural area \\
\hline
\end{tabular}

\subsection{Network Properties and Data Collection}

\subsubsection{SNA Questionnaire}

Setting up network properties is necessary to mirror the actual interactions and to display the relevant components for examining BIM applications in each project. Network boundaries are defined by the BIM communication platform for professionals and by all types of communications for tenants. Because the optimal model is implemented according to a given project, the boundaries include several tenants' representatives in urban projects-to express personnel involvement, as well as a 
closed list of professionals required at different stages and types of government projects-to compare them. Data is collected through SNA questionnaires for actors, selected by case documents and interviews, which are senior representatives of the parties to the projects and are directly involved in their communication. The questionnaire presents a detailed list of actors from which actors are asked to choose the ones they communicate with in exchange for information. They are also requested to indicate their communication frequencies with them. The urban projects require extensive preparation work to find relevant representatives of office users. For this purpose, visits and background interviews are held. In one municipality, representatives of office users, selected by the municipality's management, are guided by feedback from all municipal employees. In a second municipality, the planning team includes elected representatives from departments and offices. The questionnaires are filled out via email correspondence and through telephone interviews. In the government projects, the questionnaires are filled out by telephone interviews with representatives of the AEC (Architecture, Engineering and Construction) industry, and with the owner-occupier representatives who worked with them (the questionnaire is presented in Appendix C). Data collected is transformed into the weighting of contacts (Table in Appendix D).

\subsubsection{Participant Questionnaire}

In order to determine the validity of the measure, questionnaires for project stakeholders are set. The questionnaires are based on frameworks and models presented in the literature for assessing social sustainability and benefits from BIM. In urban projects, access is given to various personnel teams during the planning stage. Their representatives, selected by them as having access to BIM, fill out the questionnaires (five from the City Hall project, three from the station project). In the government projects, representatives of all stakeholders fill the questionnaires. For comparing them-in terms of type and stage - at the conceptual planning stage and at the detailed planning stage, 12 stakeholders are required for a cafeteria-type project and 11 for a campus-type project. These include the BIM manager, architect, constructor, air conditioning, electricity and plumbing consultants, landscape architect, project manager/owner representative, energy modeling consultant, green building consultant, and tenant representative. A cafeteria-type project also requires a special consultant. At the construction stage, a contractor is added $(13,12$, respectively). To cover all involved, experienced and inexperienced, in working with BIM, both subjective and objective assessments are combined. As part of their assessments, representatives are asked to rate, according to the Likert scale, the social benefits and effectiveness of BIM integration (1-5). In addition, objective project data is requested. Four questions deal with social aspects, including fairness, awareness, participation, and cohesion [33]. These elements are chosen because of the important conceptual presentation that identifies four general social concepts and links them to environmental imperatives. Five to seven questions, depending on the project stage, are related to subjective evaluation of a BIM implementation, which includes project quality improvement, better cost forecasting, quick client approval cycles, reduction of construction disputes, improvement of collective understanding of planning intent, reduction of construction changes, and reduction of RFI-request for information [50]. Two questions, intended for the project manager, are related to an objective evaluation of the BIM implementation and include highly mentioned metrics in the literature, schedules, and cost changes [51]. These calculation frameworks for analyzing the benefits of BIM are chosen because they summarize major subjective and objective parameters in the literature. In urban projects, where the reference is to the benefit of office users, the questionnaires are filled by a broad representation on their behalf. In the government projects, where the reference is to the benefit of involvement in various stages and types of projects, the questionnaires are filled out by all the representatives (the questionnaire is presented in Appendix E).

\subsection{Data Analysis}

The social networks are analyzed using Gephi software [52]. Gephi is an open-source network analysis and visualization software package that has been used in a number of research projects [53]. 
Weighted-degree-centrality and cluster are used to specify connections, as well as the most connected nodes, especially with respect to key actors according to the IPD-adapted model: clients-including owners and tenants, architects and contractors, or alternatively, construction managers. In the government projects, the model is adapted to the project-delivery-method used, the design-bid-build method, which involves the contractor only during the construction stage. For each project, an optimal SNA model and an actual SNA model are prepared. The optimal models are based on the forms of information transfer, which make the most of BIM in terms of sharing and engagement. The preparation of the actual models requires data filling in two tables, one representing the frequency of information giving, and the other the frequency of receiving information. After specifying the information transfers, adjustments are made according to the frequency weight, and the data is entered in Gephi software. The results of the different SNA models are used for the index equations. The index is based on the understanding that each project has unique characteristics and different social composition. Therefore, it is formulated as a tool for quantitatively assessing the performance of each green building project in relation to its optimal workability with the BIM system. Along with these findings, the evaluations of the benefits and effectiveness from the integration into the BIM application are calculated. The findings and evaluations are compared to confirm the validity of the index in an attempt to emphasize the importance of promoting social integration in green BIM to achieve its effectiveness. Figure 3 visually shows the comparisons being conducted to examine whether the social benefit level has implications for green building effectiveness and whether this is reflected in the proposed index.

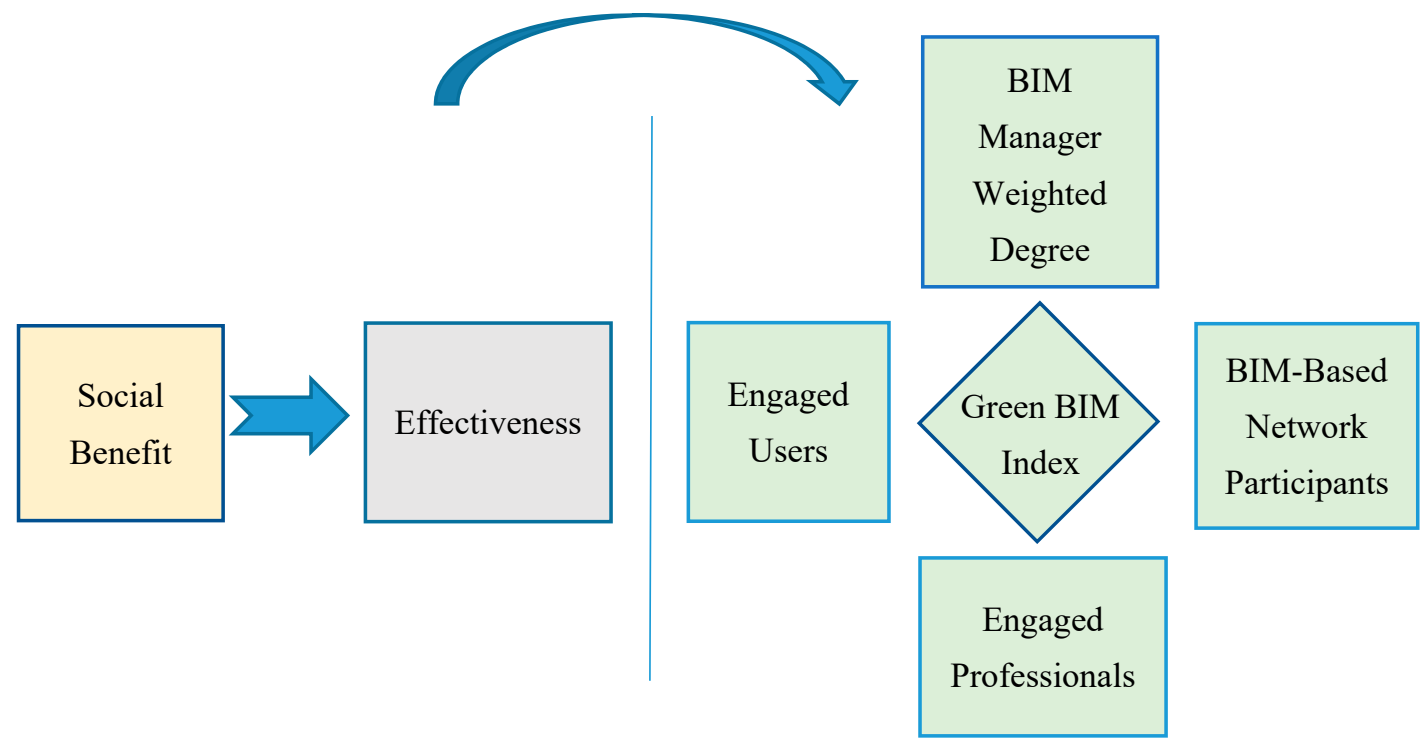

Figure 3. BIM application in terms of social benefit, effectiveness, and the proposed measure.

\section{Evaluations, Index Findings, and Their Fitting}

Table 5 presents the evaluations of social benefit and effectiveness alongside the findings of the index in each project. Each of the project parameters is averaged, sorted by levels-high $(\mathrm{H})$, medium (M), low (L)—for comparison. For this purpose, level $\mathrm{H}$-indicates a rating from $4 / 0.8$ and higher, level $\mathrm{M}$-indicates a range that reaches $2.75 / 0.55$, while $\mathrm{L}$-indicates a lower rate. Likewise, an objective estimate for the change in effectiveness is rated $\mathrm{H}$-for performance unchanged and below, $\mathrm{M}$ - for a change up to $80 \%$, and L-for change beyond that. The fit reflects identical results in the parameters. 
Table 5. Comparison of evaluations and index findings in the various projects *.

\begin{tabular}{|c|c|c|c|c|c|c|c|c|c|c|c|c|c|c|c|c|c|c|c|c|c|c|c|c|}
\hline \multirow[b]{3}{*}{ No. } & \multirow[b]{3}{*}{ Project Purpose } & \multirow[b]{3}{*}{ Stage } & \multirow{2}{*}{\multicolumn{5}{|c|}{ Social Benefit }} & \multicolumn{11}{|c|}{ Effectiveness } & \multirow{2}{*}{\multicolumn{5}{|c|}{ Green BIM Index }} & \multirow{3}{*}{ Fit } \\
\hline & & & & & & & & \multicolumn{8}{|c|}{ Subjective } & \multicolumn{3}{|c|}{ Objective } & & & & & & \\
\hline & & & 芯 & 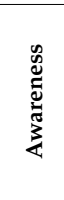 & 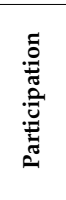 & 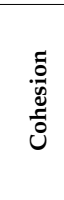 & 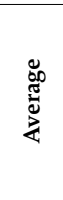 & 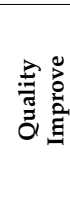 & 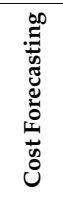 & 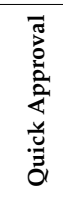 & 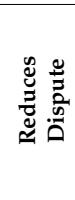 & 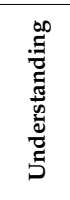 & 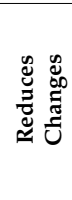 & 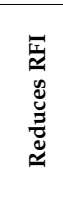 & 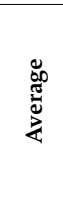 & 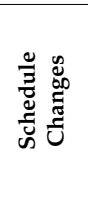 & 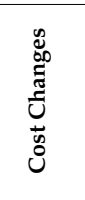 & 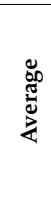 & 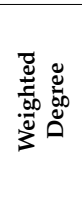 & 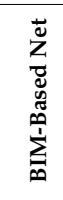 & 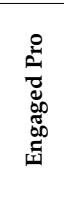 & 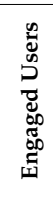 & 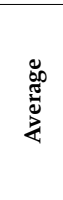 & \\
\hline 1 & City Hall & Conceptual design & 4.6 & 4.2 & 4.8 & 4.4 & $\begin{array}{c}4.5 \\
\text { H }\end{array}$ & 5 & 5 & 5 & - & 5 & - & 5 & $\begin{array}{l}\mathbf{5} \\
\mathbf{H}\end{array}$ & No & No & $\mathbf{H}$ & 0.43 & 0.96 & 0.95 & 1 & $\begin{array}{c}0.84 \\
\mathrm{H}\end{array}$ & $\checkmark$ \\
\hline 2 & Central station & Conceptual design & 5 & 4 & 4.6 & 4 & $\begin{array}{c}4.4 \\
\mathrm{H}\end{array}$ & 5 & 3 & 5 & - & 5 & - & 3 & $\begin{array}{c}4.2 \\
\text { H }\end{array}$ & No & No & $\mathbf{H}$ & 0.34 & 0.94 & 0.93 & 1 & $\begin{array}{c}0.8 \\
\mathrm{H}\end{array}$ & $\checkmark$ \\
\hline 3 & Catering & Conceptual design & 3.37 & 2.37 & 2.5 & 2 & $\begin{array}{c}2.56 \\
\text { L }\end{array}$ & 2.62 & 1.62 & 1.25 & - & 2.87 & - & 2 & $\begin{array}{c}2.07 \\
\text { L }\end{array}$ & $+100 \%$ & $+2 \%$ & $\mathbf{L}$ & 0.07 & 0.63 & 0.7 & 0 & $\begin{array}{c}0.35 \\
\text { L }\end{array}$ & $\checkmark$ \\
\hline 4 & Campus & Conceptual design & 4.77 & 4.88 & 4.66 & 4.33 & $\begin{array}{c}4.66 \\
\mathrm{H}\end{array}$ & 4.1 & 4.1 & 3.88 & - & 4 & - & 4.21 & $\begin{array}{c}4.05 \\
\text { H }\end{array}$ & No & No & $\mathbf{H}$ & 0.84 & .8 & 0.78 & 1 & $\begin{array}{c}0.85 \\
\text { H }\end{array}$ & $\checkmark$ \\
\hline 5 & Catering & Detailed design & 3.9 & 3.4 & 3.3 & 2.5 & $\begin{array}{c}3.28 \\
\mathrm{M}\end{array}$ & 3.5 & 2.2 & 2.5 & - & 3.8 & - & 3.1 & $\begin{array}{c}3.02 \\
\mathrm{M}\end{array}$ & $+71 \%$ & $+16 \%$ & $\mathbf{M}$ & 0.83 & 0.81 & 0.9 & 0 & $\begin{array}{c}0.63 \\
M\end{array}$ & $\checkmark$ \\
\hline 6 & Campus & Detailed design & 4.22 & 2.33 & 2.56 & 2.22 & $\begin{array}{c}2.83 \\
\mathrm{M}\end{array}$ & 3.44 & 1.78 & 2.22 & - & 4.1 & - & 2.55 & $\begin{array}{c}2.81 \\
\mathrm{M}\end{array}$ & $+50 \%$ & $+10 \%$ & $\mathbf{M}$ & 0.9 & 0.8 & 0.88 & 0 & $\begin{array}{c}0.64 \\
M\end{array}$ & $\checkmark$ \\
\hline 7 & Catering & Construction & 4.33 & 3.22 & 3.33 & 3.11 & $\begin{array}{l}3.5 \\
\mathrm{M}\end{array}$ & 4.11 & 3.11 & 3.22 & 4.44 & 4.78 & 3.78 & 3.22 & $\begin{array}{c}3.81 \\
\mathrm{M}\end{array}$ & No & No & $\mathbf{H}$ & 0.83 & 0.67 & 0.64 & 1 & $\begin{array}{c}0.78 \\
\text { M }\end{array}$ & $\checkmark$ \\
\hline 8 & Campus-Part 1 & Construction & 4.11 & 3 & 3.33 & 3.22 & $\begin{array}{c}3.42 \\
M\end{array}$ & 4 & 2.89 & 3.22 & 4.22 & 4.78 & 3.67 & 3.44 & $\begin{array}{c}3.75 \\
\mathbf{M}\end{array}$ & No & No & $\mathbf{H}$ & 0.78 & 0.7 & 0.7 & 1 & $\begin{array}{c}0.79 \\
\text { M }\end{array}$ & $\checkmark$ \\
\hline 9 & Campus-Part 2 & Construction & 5 & 4.44 & 4.78 & 4.67 & $\begin{array}{c}4.72 \\
\text { H }\end{array}$ & 4.67 & 4.33 & 4.89 & 4.56 & 5 & 4.22 & 3.44 & $\begin{array}{c}4.44 \\
\mathrm{H}\end{array}$ & $-10 \%$ & $-1.3 \%$ & $\mathbf{H}$ & 0.9 & 0.73 & 0.7 & 1 & $\begin{array}{c}0.83 \\
\mathrm{H}\end{array}$ & $\checkmark$ \\
\hline
\end{tabular}

* level $\mathrm{H}$-indicates a rating from $4 / 0.8$ and higher, level $\mathrm{M}$-indicates a range that reaches $2.75 / 0.55$, while L-indicates a lower rate. Likewise, an objective estimate for the change in effectiveness is rated $\mathrm{H}$ - for performance unchanged and below, $\mathrm{M}-$ for a change up to $80 \%$, and $\mathrm{L}$ - for change beyond that. 
Project \#7 - Catering - Construction - Comparison per project

Soclal benefit

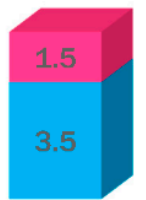

Effectiveness

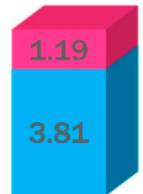

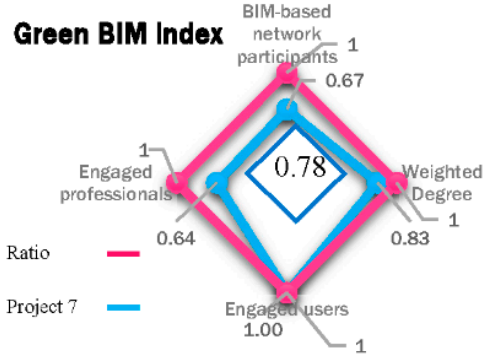

Project \#5 vs. Project \#3 - Catering - Design - Comparison per stage

Social benefit
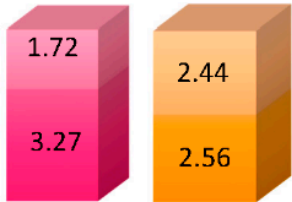

Project \#3
Effectiveness

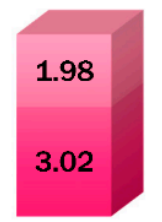

Project \#5

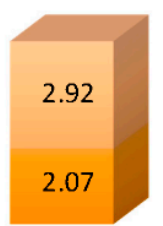

Project \#3

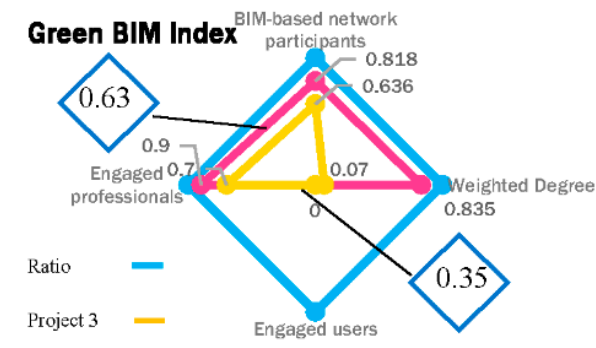

Project 5

Project \#4 vs. Project \#6 - Campus - Design - Comparison per stage

Social benefit
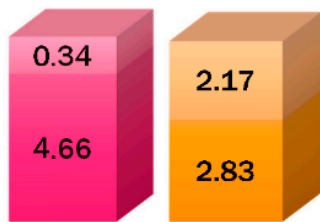

Project \#6
Effectiveness

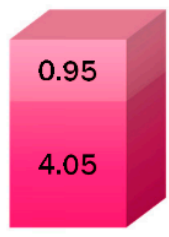

Project \#4

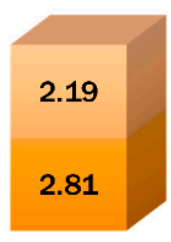

Project \#6

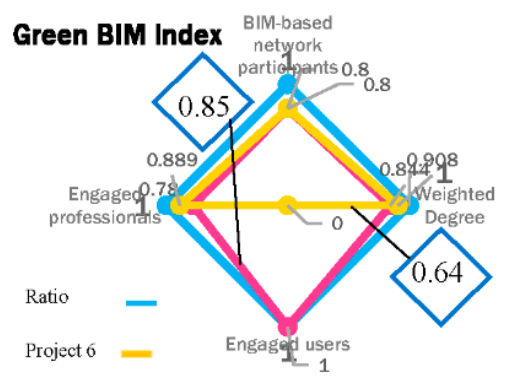

Project 4 -

Project \#9 vs. Project \#8 - Campus - Construction - Team comparison

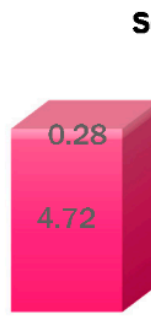

Social benefit

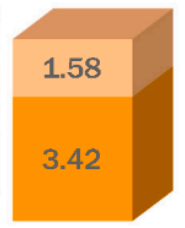

Project \#9

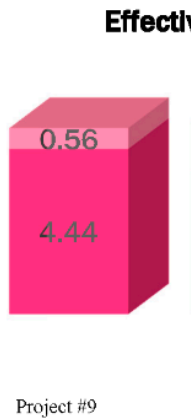

ffectiveness

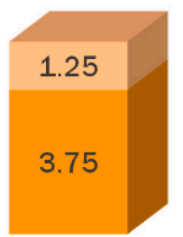

Project \#8

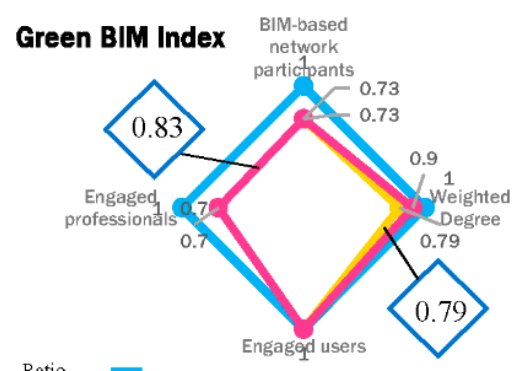

Ratio -

Project $8=$

Figure 4. Comparison of evaluations and index findings for projects by stages and teams.

In addition to this comparison of parameters for each project, Figure 4 presents a comparison of projects. The figure shows in detail the process of comparison conducted in the index between optimal implementation and actual implementation in a given project. It also presents a classification 
of projects with the same purpose, by stages and by teams, in an attempt to examine the possibility of overlap in trends between the three types of parameters.

\section{Discussion}

In this paper, the optimal BIM implementation models are characterized, for all stages and project types, to compare projects, with their social and economic implications, using BIM management measures. The tables above clearly show the relationship between social benefit and effectiveness, alongside the ability to reflect this in the proposed index.

Examining the projects reveals a fit for each project, as well as between projects-in terms of linear changes by stages and by teams in the same project. This applies to both professional and non-professional populations in projects. Social and economic background data back up the findings of the index. For example, in urban projects, there is a social attempt to integrate selected representatives of employees and municipalities into the planning team, which results in great efficiency and a high index. Projects 3 and 5 are characterized by the involvement of catering consultants, and, therefore, a special optimal BIM implementation model has been prepared. These consultants are not involved in communications, and the other professionals are not adequately skilled, resulting in unnecessary delays and expenses. However, in project number 5, the BIM manager is more involved, which has made the index different. In contrast to project 4 , in project 6 , the end-user is not involved, which has led to a late revision of the campus plan, change of schedules, and huge costs, a difference that is well reflected in the index. Projects 7,8,9 belong to the same compound and are deliberately separated for research purposes. Project 7 requires the preparation of a BIM implementation model for the construction stage, which also includes the contractor teams. Projects 8 and 9 are carried out by various teams and require, in terms of research, the preparation of a BIM implementation model for the campus in the construction stage. Although, in terms of objective effectiveness data, projects 7 and 8 are the same, and the comparison with the optimal model reveals the great work that the BIM manager has done in dealing with the lack of skills and social connection. The same BIM manager has gained greater collaboration in project number 9. This means that according to industry-standard project management parameters, the work processes required at various points of construction could not be discovered. The difference between the results is due to the resolution of the index, which is measured point-wise, compared to parameters measured over a period of the project. The index score thus allows evaluating performance and improving it further during the work, while providing a targeted response to the needs and differentiation in the project. It can be seen, therefore, that there is a direct relation between the level of social benefit and the subjective and objective levels of effectiveness per project, which is reflected in the index.

The examination validates the concept presented by the research model regarding the relationship between BIM social system and the social and economic benefits of a green building project. In examining the suitability between the management of the BIM system and the social benefit and effectiveness of its combination, it emerges that: the closer the BIM performance index is to 1 , the greater the social benefits of those involved in the project and the effectiveness. These conclusions are supported by literature on the positive effects of teamwork on project performance [54] and extend it by presenting the effect of social integration on sustainability in a green building project.

\section{Conclusions}

This study expands the understanding of the importance of social integration through BIM to achieve sustainable green building while introducing a benchmark for BIM socio-technical application to increase green building effectiveness. This importance is presented in a gradual manner through three stages, summarized below. 
1. Presentation of a socio-technical model for defining the integration of BIM with green building for sustainable benefit;

2. Presentation of a CSR-based BIM system application standard for achieving a socially sustainable effective green building project;

3. Presentation of a confirmed green BIM index as a useful tool for evaluating this application.

First, this study outlines a broad concept of green BIM, with reference to the possibility of social integration between green building and BIM. The definition of this reference is made by clarifying the social purposes of this building and the socio-technical capabilities of this system as a background for examining their actual integration. Given the gap, expressed in the absence of effective social-involvement, a BIM management application model is presented based on the CSR concept.

Second, in order to address the need, which has emerged from the literature, to integrate stakeholders into green BIM, and to use it fully in socio-technical integration, the paper has proposed a means of guiding and assessing this integration as standard. This reference is based on adapting the BIM application model to the preferred method for a green BIM project. Following the conceptualization of a project-based organization as a social network by literature, SNA is used to examine the combination of BIM and green building.

Third, through the concrete realization of the application model, this study presents a BIM system index in an attempt to bridge the gap and promote effectiveness in the green building industry. By comparing the actual application of BIM with the criteria of The BIM Integrated Application Standard, using the Green BIM Index, an option is presented to improve the flow of information and assist in the processing of information for all those involved in a green building project. This index is implemented and evaluated in nine case-studies, reflecting a variety of different types and stages of projects. The examination confirms the validity of the index and provides evidence that the more the actual use of BIM fits the proposed standard, the greater the social benefit and effectiveness of the project.

The conclusions of the study, regarding the importance of social involvement through BIM for the success of the green building, may form the basis for further research in the field. Possible research directions may include the assessment of social impact through social networks [55], as well as the use of email $\log$ [56] as empirical evidence from industry to validate the Green BIM Index and present its implications in various projects. By using a primary data source for mapping project communication networks, it is possible to compare BIM index-based projects in different industries.

This study presents for the first time a practical and feasible tool for examining BIM integration with green building, in an effort to promote the effectiveness of this combination. The presentation of this index to examine the application of building information management enables the construction industry to examine the social responsibility of green building companies in relation to their stakeholders along the supply chain. As a result, this study may have implications for the perception of a green building project as a sustainable project. In the green BIM projects, which are more socially complex and technologically sophisticated than regular projects, implementing the Green BIM Index, which facilitates stakeholder integration, may be of great benefit to the industry.

Author Contributions: R.M.-L. conceived the research, collected and analyzed the data, drafted, and edited. U.G. collected objective data from government projects and reviewed the draft. I.R.- guidance of data analyses, literature review support, revision of manuscript for important intellectual content, supervision. All authors read and agreed to the published version of the manuscript.

Funding: This research received no external funding.

Acknowledgments: The authors would like to thank the experts who reviewed the manuscript.

Conflicts of Interest: The authors declare no conflict of interest. 


\section{Appendix A. The Conceptual Description for BIM Integrated Application Standard Components}

\begin{tabular}{|c|c|c|c|}
\hline & Criteria & SNA Indices & Basic Assumptions \\
\hline 1 & $\begin{array}{l}\text { Stakeholder } \\
\text { management }\end{array}$ & $\begin{array}{l}\text { Weighted degree centrality. In order to } \\
\text { examine the centrality of the BIM } \\
\text { manager as a management implementer } \\
\text { in terms of stakeholders, the study uses } \\
\text { the means of weighted degree centrality. } \\
\text { The BIM manager is important if there } \\
\text { are many other nodes-actors that link } \\
\text { to him/her or if he/she links to many } \\
\text { other nodes. Weighted degree centrality } \\
\text { of a node is 'the sum of weights of the } \\
\text { ties of the node with the other nodes' } \\
\text { (Kapoor et al., 2013). It follows that the } \\
\text { higher the centrality, the greater the } \\
\text { BIM management leadership. }\end{array}$ & $\begin{array}{l}\text { The standard assumption regarding the } \\
\text { BIM manager, based on preliminary } \\
\text { research, is that he/she sends } \\
\text { information to everyone daily, receives } \\
\text { information from key participants on a } \\
\text { daily basis, receives information from } \\
\text { the secondary to them weekly while } \\
\text { receiving from other participants on a } \\
\text { monthly basis. These transitions are } \\
\text { required for optimal application. To } \\
\text { manage stakeholders, it is suggested } \\
\text { that the BIM manager should have a } \\
\text { high level of weighted degree centrality, } \\
\text { as standard. }\end{array}$ \\
\hline 2 & Stakeholder participation & $\begin{array}{l}\text { Cluster. In order to examine the } \\
\text { participation of stakeholders in a } \\
\text { specific workgroup, the research is } \\
\text { based on a cluster approach. Cluster } \\
\text { nodes are 'more connected with nodes } \\
\text { of this cluster than with nodes outside } \\
\text { the cluster' (Cuvelier and Aufaure, } \\
\text { 2012). Finding a cluster is based on how } \\
\text { they are connected to one another, and } \\
\text { therefore, according to that, it is } \\
\text { possible to describe a shared connection } \\
\text { or access to joint resources in a project. }\end{array}$ & $\begin{array}{l}\text { It is proposed that all involved, } \\
\text { professionals and tenants alike, should } \\
\text { be connected, directly or indirectly, to a } \\
\text { BIM-based social network. } \\
\text { The reference in this BIM indicator is to } \\
\text { participants in an IPD-based } \\
\text { cross-border coordination mechanism. } \\
\text { This technological accessibility, as an } \\
\text { expression of the possibility of equal } \\
\text { participation as a conscious group, is } \\
\text { required for optimal application in a } \\
\text { given project. }\end{array}$ \\
\hline 3 & $\begin{array}{l}\text { All professional } \\
\text { stakeholders are engaged }\end{array}$ & \multirow[b]{2}{*}{$\begin{array}{l}\text { Ego net cluster. In order to examine the } \\
\text { way stakeholders are involved and their } \\
\text { connectivity as a group, the research is } \\
\text { assisted by means of ego nets clusters. } \\
\text { Ego nets represent the connections } \\
\text { among the neighbors of a given node } \\
\text { (Epasto et al., 2015). In an attempt to } \\
\text { locate a community of direct contacts } \\
\text { with the BIM manager and the tenant } \\
\text { representative, it is suggested that the } \\
\text { size measure be used as algorithms for } \\
\text { identifying communities or clusters, } \\
\text { thus allowing specifying the number of } \\
\text { participants in the BIM manager and } \\
\text { the tenant representative groups. Since } \\
\text { the size of an ego-network is considered } \\
\text { as the amount of neighboring nodes } \\
\text { plus the ego (Hanneman and Riddle, } \\
\text { 2005), it is possible to specify the direct } \\
\text { links to them. }\end{array}$} & \multirow[b]{2}{*}{$\begin{array}{l}\text { The participation can be divided into } \\
\text { sub-clusters. The references in these } \\
\text { BIM indicators are in relation to the } \\
\text { manner in which the different } \\
\text { participants are involved. With regard } \\
\text { to the engagements of all professional } \\
\text { and non-professional, it is proposed to } \\
\text { define the ego nets of the BIM manager } \\
\text { and the tenant representative, equal to } \\
\text { the maximum possible size for each. } \\
\text { The standard assumption, based on the } \\
\text { need for management of stakeholders } \\
\text { through the BIM manager, to promote } \\
\text { information flow and full processing, is } \\
\text { that there is no interaction except } \\
\text { through a BIM-based network and with } \\
\text { a BIM manager or agents. }\end{array}$} \\
\hline 4 & Tenants are engaged & & \\
\hline 5 & $\begin{array}{l}\text { Management, } \\
\text { participation, } \\
\text { engagements at all } \\
\text { phases, within a project }\end{array}$ & $\begin{array}{l}\text { The examination of the management of } \\
\text { stakeholders-their participation and } \\
\text { engagement-is required throughout } \\
\text { the project. }\end{array}$ & $\begin{array}{l}\text { The basic assumptions above regarding } \\
\text { the indices in each criterion are applied } \\
\text { at the design, construction, and } \\
\text { maintenance phases, according to a } \\
\text { given project. }\end{array}$ \\
\hline
\end{tabular}

\section{Appendix B. The Equations of the Green BIM Index}

The suitability between the results of the actual implementation of BIM and the results of the optimal application of the BIM standard proposed by the study is expressed in the BIM application index, which can be presented in the equation (Equation (A1)):

$$
\text { BIM Application Index }(X)=\frac{\text { The Actual Application of BIM }}{\text { Standard for Optimal Application of BIM }}
$$


The comparison is applied in a number of formulas for examining the suitability in the various BIM standard parts:

1. Stakeholder Management (Equation (A2))

$$
\text { Weighted Degree Centrality Index }(X 1)=\frac{\text { Weighted Dedree }}{\text { Standard Weighted degree }}
$$

2. Stakeholder Participation (Equation (A3))

$$
\text { BIM - Based Social Net Clustering Index (X2) }=\frac{\sum \text { Stakeholders Connected }}{\text { Stakeholder Standard }}
$$

3. Involvement of Professionals (Equation (A4))

$$
\text { Ego-Net Cluster Index of BIM Manager }(X 3)=\frac{\sum \text { BIM Manager Connections }}{\text { BIM Manager Connections Standard }}
$$

4. Involvement of Tenants (Equation (A5))

$$
\text { Ego-Net Cluster Index of Tenant Representative }(X 4)=\frac{\sum \text { Tenants Rep.Connections }}{T . \text { Rep. Connections Standard }}
$$

5. The Application of BIM System at one of the building phases (Equation (A6))

$$
\text { BIM Index by phase }(X 5)=\frac{X 1+X 2+X 3+X 4}{4}
$$

The higher the suitability, the more the result of the index is close to 1.00. This means that as the

\begin{tabular}{|c|c|c|c|c|}
\hline Receiving Information & \multicolumn{4}{|c|}{ Frequencies } \\
\hline Mark the Respondent & Daily & Weekly & Monthly & No interaction \\
\hline \multicolumn{5}{|l|}{ BIM manager } \\
\hline \multicolumn{5}{|l|}{ Architect } \\
\hline \multicolumn{5}{|l|}{ Constructor } \\
\hline \multicolumn{5}{|l|}{$\mathrm{AC}$ engineer } \\
\hline \multicolumn{5}{|l|}{ Electrical engineer } \\
\hline \multicolumn{5}{|l|}{ Plumbing engineer } \\
\hline \multicolumn{5}{|l|}{ Landscape architect } \\
\hline \multicolumn{5}{|l|}{ Project manager } \\
\hline \multicolumn{5}{|l|}{ BEM consultant } \\
\hline \multicolumn{5}{|l|}{ GB consultant } \\
\hline \multicolumn{5}{|l|}{ Tenant } \\
\hline \multicolumn{5}{|l|}{ * Contractor } \\
\hline * Cafeteria consultant & & & & \\
\hline
\end{tabular}
BIM management team is more centralized in the network, as network sharing becomes apparent, for the connectivity of all involved, professionals and end-users alike, at any phase of the building, the performance of the project may be relatively more social.

\section{Appendix C. SNA Questionnaire}




\begin{tabular}{|c|c|c|c|c|}
\hline Giving Information & \multicolumn{4}{|c|}{ Frequencies } \\
\hline Mark the Respondent & Daily & Weekly & Monthly & No Interaction \\
\hline \multicolumn{5}{|l|}{ BIM manager } \\
\hline \multicolumn{5}{|l|}{ Architect } \\
\hline \multicolumn{5}{|l|}{ Constructor } \\
\hline \multicolumn{5}{|l|}{ AC Engineer } \\
\hline \multicolumn{5}{|l|}{ Electrical engineer } \\
\hline \multicolumn{5}{|l|}{ Plumbing engineer } \\
\hline \multicolumn{5}{|l|}{ Landscape architect } \\
\hline \multicolumn{5}{|l|}{ Project manager } \\
\hline \multicolumn{5}{|l|}{ BEM consultant } \\
\hline \multicolumn{5}{|l|}{ GB consultant } \\
\hline \multicolumn{5}{|l|}{ Tenant } \\
\hline \multicolumn{5}{|l|}{ * Contractor } \\
\hline * Cafeteria consultant & & & & \\
\hline
\end{tabular}

* By project type or project stage.

\section{Appendix D. Weighting of Information Flow}

\begin{tabular}{ccl}
\hline Level of Information Flow & Weighting of Connection & \multicolumn{1}{c}{ Reasoning } \\
\hline Never & 0 & \\
Monthly & 1 & At least once a month \\
Weekly & 5 & At least 4 per month \\
Daily & 22 & At least 5 per week \\
\hline
\end{tabular}

\section{Appendix E. Participant Questionnaire}

Appendix E.1. Social Benefits

\begin{tabular}{lll}
\hline 1 & $\begin{array}{l}\text { Have you been given open or equal access, relative to the other } \\
\text { participants, to the project's BIM forum? }\end{array}$ & $1-5$ \\
\hline 2 & $\begin{array}{l}\text { Did you get the opportunity to promote awareness, non-material } \\
\text { ethical preferences, in the project's BIM forum? }\end{array}$ & $1-5$ \\
\hline & $\begin{array}{l}\text { Were you involved, independently or through delegates, in the } \\
\text { BIM forum, so that your preferences were reflected in the } \\
\text { decision-making process? }\end{array}$ & $1-5$ \\
\hline 4 & $\begin{array}{l}\text { Have you been involved in the BIM forum, in a way that allowed } \\
\text { you to work as a team or feel part of teamwork? }\end{array}$ & $1-5$ \\
\hline
\end{tabular}


Appendix E.2. Effectiveness

\begin{tabular}{|c|c|c|}
\hline 1 & How has BIM's specific use/application improved the quality of the project? & $1-5$ \\
\hline 2 & $\begin{array}{l}\text { How has the specific use/application of BIM improved the predictability of } \\
\text { project costs? }\end{array}$ & $1-5$ \\
\hline 3 & How has BIM's specific use/application improved client approval speed? & $1-5$ \\
\hline 4 & $\begin{array}{l}\text { How has the specific use/application of BIM reduced conflicts during } \\
\text { construction? }{ }^{*}\end{array}$ & $1-5$ \\
\hline 5 & $\begin{array}{l}\text { How has the specific use/application of BIM enhanced the collective } \\
\text { understanding of planning intentions? }\end{array}$ & $1-5$ \\
\hline 6 & $\begin{array}{l}\text { How has the specific use/application of BIM reduced changes during } \\
\text { construction? * }\end{array}$ & $1-5$ \\
\hline 7 & $\begin{array}{l}\text { How has the specific use/application of BIM reduced the number of } \\
\text { information requests on your part? }\end{array}$ & $1-5$ \\
\hline
\end{tabular}

\section{References}

1. McGraw Hill Construction. Green BIM: How Building Information Modeling Is Contributing to Green Design and Construction. Available online: http://construction.com/market_research/FreeReport/GreenBIM/ MHC_GreenBIM_SmartMarket_Report_2010.pdf (accessed on 26 June 2020).

2. Wu, W.; Issa, R. Integrated process mapping for BIM implementation in green building project delivery. In Proceedings of the 13th International Conference on Construction Applications of Virtual Reality, London, UK, 30-31 October 2013; pp. 30-39.

3. USGBC. What Is Green Building? U.S. Green Building Council. Available online: https://www.usgbc.org/ articles/what-green-building (accessed on 26 June 2020).

4. NIBS. What Is BIM? National Institute of Building Sciences. Available online: https://web.archive.org/web/ 20141016190503/http://www.nationalbimstandard.org/faq.php\#faq1 (accessed on 26 June 2020).

5. Lu, Y.; Wu, Z.; Chang, R.; Li, Y. Building Information Modeling (BIM) for green buildings: A critical review and future directions. Autom. Constr. 2017, 83, 134-148. [CrossRef]

6. Azhar, S.; Carlton, W.A.; Olsen, D.; Ahmad, I. Building information modeling for sustainable design and LEED $^{\circledR}$ rating analysis. Autom. Constr. 2011, 20, 217-224. [CrossRef]

7. Wong, J.K.W.; Zhou, J. Enhancing environmental sustainability over building life cycles through green BIM: A review. Autom. Constr. 2015, 57, 156-165. [CrossRef]

8. El-Diraby, T.; Krijnen, T.; Papagelis, M. BIM-Based collaborative design and socio-technical analytics of green buildings. Autom. Constr. 2017, 82, 59-74. [CrossRef]

9. Ayman, R.; Alwan, Z.; McIntyre, L. BIM for sustainable project delivery: Review paper and future development areas. Archit. Sci. Rev. 2020, 63, 15-33. [CrossRef]

10. Stender, M.; Walter, A. The role of social sustainability in building assessment. Build. Res. Inf. 2019, 47, 598-610. [CrossRef]

11. Bonenberg, W.; Kapliński, O. The architect and the paradigms of sustainable development: A review of dilemmas. Sustainability 2018, 10, 100. [CrossRef]

12. Gandhi, S.; Jupp, J.R. Characteristics of Green BIM: Process and information management requirements. In IFIP International Conference on Product Lifecycle Management; Springer: Berlin, Germany, 2013; pp. 596-605.

13. Gourlis, G.; Kovacic, I. Building information modelling for analysis of energy efficient industrial buildings-A case study. Renew. Sustain. Energy Rev. 2017, 68, 953-963. [CrossRef]

14. Wong, K.; Fan, Q. Building information modelling (BIM) for sustainable building design. Facilities 2013, 31, 138-157. [CrossRef]

15. Gerrish, T.; Ruikar, K.; Cook, M.; Johnson, M.; Phillip, M. Using BIM capabilities to improve existing building energy modelling practices. Eng. Constr. Archit. Manag. 2017, 24, 190-208. [CrossRef]

16. Wong, J.; Wang, X.; Li, H.; Chan, G.; Li, H. A review of cloud-based BIM technology in the construction sector. J. Inf. Technol. Constr. 2014, 19, 281-291. 
17. Antón, L.Á.; Díaz, J. Integration of LCA and BIM for sustainable construction. Int. J. Soc. Behav. Educ. Econ. Bus. Ind. Eng. 2014, 8, 1378-1382.

18. Olawumi, T.O.; Chan, D.W.M. Critical success factors for implementing building information modeling and sustainability practices in construction projects: A Delphi survey. Sustain. Dev. 2019, 27, 587-602. [CrossRef]

19. Harding, J.; Suresh, S.; Renukappa, S.; Mushatat, S. Do building information modelling applications benefit design teams in achieving BREEAM accreditation? J. Constr. Eng. 2014. [CrossRef]

20. Raouf, A.M.I.; Al-Ghamdi, S.G. Building information modelling and green buildings: Challenges and opportunities. Archit. Eng. Des. Manag. 2018, 15, 1-28. [CrossRef]

21. Chong, H.-Y.; Lee, C.-Y.; Wang, X. A mixed review of the adoption of building information modelling (Bim) for sustainability. J. Clean. Prod. 2017, 142, 4114-4126. [CrossRef]

22. Liu, Z.; Lu, Y.; Peh, L.C. A Review and Scientometric Analysis of Global Building Information Modeling (BIM) Research in the Architecture, Engineering and Construction (AEC) Industry. Buildings 2019, 9, 210. [CrossRef]

23. Atanda, J.O.; Öztürk, A. Social criteria of sustainable development in relation to green building assessment tools. Environ. Dev. Sustain. 2018, 22. [CrossRef]

24. Maltese, S.; Tagliabue, L.C.; Cecconi, F.R.; Pasini, D.; Manfren, M.; Ciribini, A.L. Sustainability assessment through green BIM for environmental, social and economic efficiency. Procedia Eng. 2017, 180, 520-530. [CrossRef]

25. Acampa, G.; Ordóñez García, J.; Grasso, M.; Díaz-López, C. Project sustainability: Criteria to be introduced in BIM. J. Valori Valutazioni 2019, 23, 119-128.

26. Almahmoud, E.; Doloi, H.K. Assessment of social sustainability in construction projects using social network analysis. Facilities 2015, 33, 152-176. [CrossRef]

27. Wang, H.; Zhang, X.; Lu, W. Improving social sustainability in construction: Conceptual framework based on social network analysis. J. Manag. Eng. 2018, 34, 05018012. [CrossRef]

28. Zhao, Z.Y.; Zhao, X.J.; Davidson, K.; Zuo, J. A corporate social responsibility indicator system for construction enterprises. J. Clean. Prod. 2012, 29, 277-289. [CrossRef]

29. Asif, M.; Searcy, C.; Zutshi, A.; Fisscher, O.A.M. An integrated management systems approach to corporate social responsibility. J. Clean. Prod. 2013, 56, 7-17. [CrossRef]

30. Roberts, R.W. Determinants of corporate social responsibility disclosure: An application of stakeholder theory. Account. Organ. Soc. 1992, 17, 595-612. [CrossRef]

31. Carroll, A.B. The pyramid of corporate social responsibility: Toward the moral management of organizational stakeholders. Bus. Horiz. 1991, 34, 39-48. [CrossRef]

32. Freeman, R.E. Strategic Management: A Stakeholder Approach; Pitman: Boston, MA, USA, 1984.

33. Murphy, K. The social pillar of sustainable development: A literature review and framework for policy analysis. Sustain. Sci. Pract. Policy 2012, 8, 15-29. [CrossRef]

34. Kent, D.C.; Becerik-Gerber, B. Understanding construction industry experience and attitudes toward integrated project delivery. J. Constr. Eng. Manag. 2010, 136, 815-825. [CrossRef]

35. AIA. Integrated Project Delivery: A Guide; The American Institute of Architects: Washington, DC, USA, 2007.

36. Yee, L.S.; Saar, C.C.; Yusof, A.M.; Chuing, L.S.; Chong, H.Y. An empirical review of integrated project delivery (IPD) System. Int. J. Innov. Manag. Technol. 2017, 8, 1-8. [CrossRef]

37. NASFA; COAA; APPA; AGC; AIA. Integrated Project Delivery for Public and Private Owners; National Association of State Facilities Administrators (NASFA); Construction Owners Association of America (COAA); APPA: The Association of Higher Education Facilities Officers; Associated General Contractors of America (AGC); American Institute of Architects (AIA): Austell, GA, USA, 2010.

38. Wasserman, S.; Faust, K. Social Network Analysis: Methods and Applications; Cambridge University Press: Cambridge, UK, 1994.

39. Kapoor, K.; Sharma, D.; Srivastava, J. Weighted Node Degree Centrality for Hypergraphs. In Proceedings of the 2013 IEEE 2nd Network Science Workshop (NSW), West Point, NY, USA, 29 April-1 May 2013; pp. 152-155.

40. Cuvelier, E.; Aufaure, M.A. Graph mining and communities detection. In Business Intelligence; Aufaure, M.A., Zimanyi, E., Eds.; Springer: Berlin, Germany, 2012; Volume 96, pp. 117-138.

41. Epasto, A.; Lattanzi, S.; Mirrokni, V.; Sebe, I.O.; Taei, A.; Verma, S. Ego-Net Community Mining Applied to Friend Suggestion. Proc. VLDB Endow. 2015, 9, 324-335. [CrossRef] 
42. Hanneman, R.A.; Riddle, M. Introduction to Social Network Methods; University of California: Riverside, CA, USA, 2005.

43. Pryke, S. Social Network Analysis in Construction; Wiley: Hoboken, NJ, USA, 2012.

44. Reychav, I.; Maskil Leitan, R.; McHaney, R. Sociocultural sustainability in green building information modeling. Clean Technol. Environ. Policy 2017, 19, 2245-2254. [CrossRef]

45. Maskil-Leitan, R.; Reychav, I. A sustainable sociocultural combination of building information modeling with integrated project delivery in a social network perspective. Clean Technol. Environ. Policy 2018, 20, 1017-1032. [CrossRef]

46. Sacks, R.; Gurevich, U.; Shrestha, P. A review of building information modeling protocols, guides and standards for large construction clients. J. Inf. Technol. Constr. (ITcon) 2016, 21, 479-503.

47. Wang, H. The Interplay of Formal and Informal Institutions for Procurement Innovation: A Social Network Approach. Ph.D. Thesis, The University of Hong Kong, Hong Kong, China, 2015.

48. Yin, R.K. Case Study Research: Design and Methods, 5th ed.; Sage: Thousand Oaks, CA, USA, 2014.

49. Simons, H. Case Study Research in Practice; Sage: London, UK, 2009.

50. Yang, J.B.; Chou, H.Y. Subjective benefit evaluation model for immature BIM-enabled stakeholders. Autom. Constr. 2019, 106, 102908. [CrossRef]

51. Barlish, K.; Sullivan, K. How to measure the benefits of BIM-A case study approach. Autom. Constr. 2012, 24, 149-159. [CrossRef]

52. Bastian, M.; Heymann, S.; Jacomy, M. Gephi: An open source software for exploring and manipulating networks. In Proceedings of the Third International Conference on Weblogs and Social Media (ICWSM 2009), San Jose, CA, USA, 17-20 May 2009.

53. Malisiovas, A.; Song, X. Social Network Analysis (SNA) for construction projects' team communication structure optimization. In Proceedings of the Construction Research Congress 2014, American Society of Civil Engineers (ASCE), Atlanta, GA, USA, 19-21 May 2014; pp. 2032-2042.

54. Franz, B.; Leicht, R.; Molenaar, K.; Messner, J. Impact of team integration and group cohesion on project delivery performance. J. Constr. Eng. Manag. 2016, 143, 04016088. [CrossRef]

55. Acampa, G.; Grasso, M.; Marino, G.; Parisi, C.M. Tourist flow management: Social impact evaluation through social network analysis. Sustainability 2020, 12, 731. [CrossRef]

56. Du, J.; Zhao, D.; Issa, R.R.A.; Singh, N. BIM for improved project communication networks: Empirical evidence from email logs. J. Comput. Civ. Eng. 2020, 34, 04020027. [CrossRef] 